\title{
Goods Stock Management using the K-Means Algorithm Method
}

\author{
Dhio Saputra \\ ${ }^{1}$ Fakultas Ilmu Komputer, Universitas Putra Indonesia YPTK, Indonesia \\ E-mail:dhio_saputra@upiyptk.ac.id
}

\begin{abstract}
The grouping of Mazaya products at PT. Bougenville Anugrah can still do manuals in calculating purchases, sales and product inventories. Requires time and data. For this reason, a research is needed to optimize the inventory of Mazaya goods by computerization. The method used in this research is K-Means Clustering on sales data of Mazaya products. The data processed is the purchase, sales and remaining inventory of Mazaya products in March to July 2019 totaling 40 pieces. Data is grouped into 3 clusters, namely cluster 0 for nonselling criteria, cluster 1 for best-selling criteria and cluster 2 for very best-selling criteria. The test results obtained are cluster 0 with 13 data, cluster 1 with 25 data and cluster 2 with 2 data. So to optimize inventory is to multiply goods in cluster 2, so as to save costs for management of Mazaya products that are not available. K-Means clustering method can be used for data processing using data mining in grouping data according to criteria.
\end{abstract}

Keyword: K-Means, Data Mining, Clustering, Cluster, Pengelompokan

\section{INTRODUCTION}

Data Mining can be implemented to group data in various cases, such as grouping the Human Immunodeficiency Virus / Acquired Immunodeficiency Syndrome (HIV / AIDS) indicator in Indonesia based on 34 provinces in Indonesia [1]. Data Mining with the K-Means Clustering algorithm has also been used to determine which employees are eligible to take part in the Assessment Center for the SDP program [2].

PT. Bougenville Anugrah is a company as a distributor of PT. Pesona Amaranthine Cosmetiques which is engaged in Mazaya Cosmetics. Due to the large number of Mazaya product data and stock items that must be analyzed, a management must work hard in analyzing and determining the next item to be purchased from the existing stock.

Based on the problems that have been described, this research will produce information about the grouping of mazaya product sales from "NOT LARIS", "LARIS" and "VERY LARIS", then it will be calculated from the existing sales using the K-Means Clustering method with the application. RapidMinner Studio, then the results can be used as a guide or knowledge base in restoring goods, especially for mazaya products at PT. Bougenville Grace.

Diterima Redaksi : 18-04-2020 | Selesai Revisi : 18-04-2020 | Diterbitkan Online : 30-04-2020 


\section{LITERATURE}

Knowledge Discovery in Database (KDD) is a method used to obtain knowledge from existing databases. The results of the knowledge obtained can be used as a knowledge base that is used for decision making purposes [3].

Data mining is the process of finding interesting patterns and knowledge of large amounts of data. Data sources can include databases, data warehouses, web, other information repositories, or data that is streamed into a dynamic system. Data mining is commonly used for classification, clustering, prediction, estimation, association and data description [4].

One of the grouping techniques of data mining is clustering. Clustering is the process of dividing data into classes or clusters based on the level of similarity. In clustering, data that have similarities are entered into the same cluster, while data that have no similarities are entered into different clusters [5].

The K-Means algorithm is a non-hierarchical data clustering method that attempts to partition existing data into one or more clusters / groups. This method partitions the data into clusters / groups so that data that has the same characteristics are grouped into the same cluster and data that has different characteristics are grouped into other groups [6].

The K-Means algorithm will group objects into K clusters. This method will search for cluster centers and cluster boundaries through an iterative process. The proximity or similarity of an object to another object or the center of the cluster is calculated using the distance function. In general, K-Means use the Euclidean distance to calculate these similarities [7].

1. The calculation steps using the K-Means algorithm are:

2. 1. Determine the value of $\mathrm{k}$ as the number of clusters to be formed;

3. 2. Determine the initial $\mathrm{k}$ centroid (cluster center point) randomly;

4. 3. Calculate the distance of each data to each cendroid using the correlation formula between two objects such as the Euclidean Distance formula;

$$
d_{i j}=\sqrt{\left(x_{i}-x_{j}\right)^{2}+\left(y_{i}-y_{j}\right)^{2}}
$$

Information:

$\operatorname{dij}=$ distance between $\mathrm{i}$ and $\mathrm{j}$

$\mathrm{xi}=$ the $\mathrm{x}$ coordinate of the object

$\mathrm{xj}=$ center $\mathrm{x}$ coordinate

$\mathrm{yi}=$ the object's $\mathrm{y}$ coordinate

$\mathrm{yj}=$ center $\mathrm{y}$ coordinate

5. 5. Classify each data based on the closest distance between the data and the centroid;

6. 6. Determine the position of the new centroid by calculating the average value of existing data in the same cluster.

$$
C i=\frac{x 1+x 2+x 3+\cdots+x n}{x}
$$

Information:

$\mathrm{x} 1=$ the value of the 1 st data record

$\mathrm{x} 2=2$ nd record data value

$\sum \mathrm{x}=$ number of data records

7. Return to step 3 if the position of the new centroid with the old centroid is not the same [8]. 


\section{METHOD}

In the preparation of this study, the framework used can be seen in the following figure:

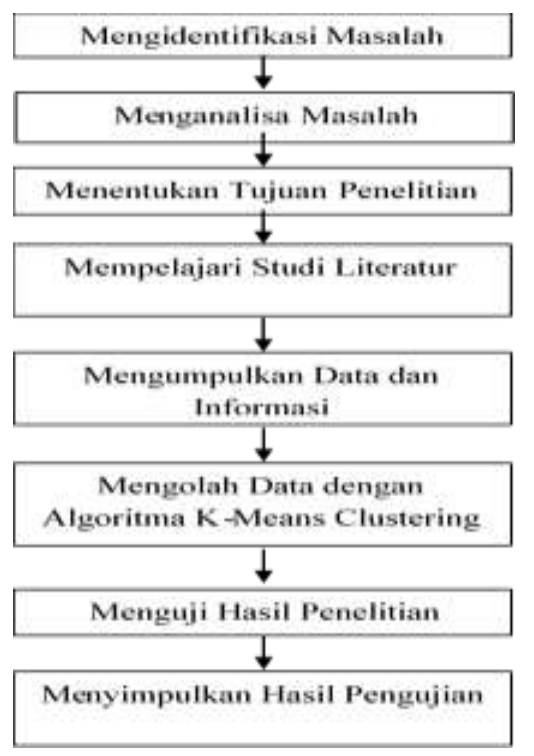

Information :

\section{Figure 1: Research Framework}

1. Identify the Problem

The problem identified in this study is to classify Mazaya products to optimize the stocks of Mazaya products at PT.Bougenville Anugrah.

\section{Analyzing the Problem}

At this stage, a problem analysis is carried out to be able to understand the problems that have been determined in scope or boundaries and identify problems. By analyzing the predetermined problems, it is hoped that the problem can be understood well.

3. Determining Research Objectives

After the problem can be understood, at this stage the objectives to be achieved through the research process are stated. In this study, the goal to be achieved is to determine the clusters of mazaya products, there are 3 clusters, namely: (C0) Not Selling, (C1) Selling, (C2) Very Selling.

4. Studying Literature Studies

At this stage the researcher studies the literature study related to the research title. Literature sources are obtained from journals that discuss the K-Means Clustering Algorithm, Data Mining and other reading materials that support this research.

5. Collecting Data and Information

The purpose of this stage is to obtain information about products that are not selling, selling, and are selling well based on test results. The collection of data and information is carried out in several ways, such as searching for and studying literature and journal studies, making observations by making direct observations to PT. Bougenville Anugrah to obtain the required data and then conduct interviews with parties directly related to the problems being discussed in this study to get a more detailed description and explanation, so that the desired data can be achieved, namely complete and accurate data. 


\section{Processing Data with the K-Means Clustering Algorithm}

At this stage, the data that has been obtained at the data collection stage will be processed and processed with the K-Means Clustering Algorithm, the steps are as follows:

a. Determine the number of clusters $\mathrm{K}$

b. Randomly determine the center of the centroid

c. Calculates the closest distance to the centroid

d. Group data into each cluster

7. Testing Research Results

The author conducts training and testing after collecting data, processing the K-Means clustering algorithm, and installing the software that will be used, namely Rapid Miner, for further training and testing of the data. Testing is data obtained from initial data processing using the K-Means clustering method. The results obtained from the test will be analyzed so that the conditions are more accurate.

8. Concluding the test results

At this stage the writer will get the results of the K-Means Clustering Algorithm calculation using Excel and the Rapid Miner application. From the results of this grouping, several groups of mazaya products will be obtained according to their respective clusters, and the author can recommend the results to the management of PT. Bougenville Anugrah as a consideration for decision making to optimize Mazaya stock.

\section{RESULT}

From the Knowledge Discovery in Database (KDD), the K-Means Clustering algorithm can be understood that the steps for solving it can be explained as follows:

\section{Data Selection Process}

In the Knowledge Discovery in Database (KDD) process, data selection is the process of data collection and creating target data on the data sample, where the discovery will be made and the selection results are stored in a separate file from the operational database data. After the data is obtained from PT. Bougenville Anugrah, like the initial data above, a data selection process is carried out, this process is carried out to facilitate the calculation process of the K-Means Clustering algorithm. The data used are data from March to July 2019.

\section{Data Input}

The data entered is the data that has been obtained from PT. Bougenville Anugrah from March to July 2019 which can be seen in table 1 above. Before inputting the data into the system, it must be analyzed and carried out the calculation process correctly, while the process of the K-means clustering algorithm is as follows:

a. Determine the number of clusters $(\mathrm{K})$

$\mathrm{K}$ here is the number of clusters to be formed. In this study, 3 types of clusters were formed, namely purchasing, selling and remaining stock obtained from the monthly data recapitulation of Mazaya PT. Bougenville Anugrah which was taken from March to July 2019, the cluster is divided into non-selling, best-selling and very in-demand.

b. Randomly Determining the Center Point of the Centroid

After determining the number of clusters as many as 3 clusters, then the center point is determined randomly here taken for the center cluster $0(\mathrm{C} 0)$ : taken from number 5 for the 
center cluster $1(\mathrm{C} 1)$ : taken from number 18 and the center of cluster $2(\mathrm{C} 2)$ : taken from number 31 can be seen from the random value table as follows :

Table 1: Random Centroid Values

\begin{tabular}{|c|c|c|c|}
\hline Centroid & Pembelian & Penjualan & Sisa Stok \\
\hline $\mathbf{C}_{\boldsymbol{0}}$ & 181 & 173 & 8 \\
\hline $\mathbf{C}_{\boldsymbol{1}}$ & 96 & 81 & 15 \\
\hline $\mathbf{C}_{\boldsymbol{2}}$ & 302 & 257 & 45 \\
\hline
\end{tabular}

a. Calculates the Nearest Centroid Distance

The euclidean distance formula is used to calculate the distances of the center object to each centroid so that the closest distance from each data to the centroid is found. The following is the equation formula Classifying the data for each cluster Classify each data based on its proximity to the shortest distance centroid. The calculation process is as follows:

1) Iteration Process I (First)

To calculate the center of cluster 0 , cluster 1 and cluster 2, at this stage the distance of each data will be calculated using the Euclidean Distance (D) formula in the first iteration. Calculate the distance of each data to the center point as follows:

Euclidean Distance formula:

$D_{L_{i}}\left(x_{2}, x_{1}\right)=\left\|x_{2}-x_{1}\right\| \sum_{j=1}^{p}\left|x_{2 j}-x_{i j}\right| \quad D_{L_{2}}=\left(x_{2}, x_{1}\right)=\left\|x_{2}-x_{1}\right\|=\sqrt{\sum_{j=1}^{p}\left(x_{2 j}-x_{1 j}\right)^{2}}$

1. Proses Hitung cluster $\left(\mathrm{C}_{0}\right)$

$$
\begin{aligned}
& X_{1}=(66 ; 21 ; 45) \quad C_{1.1}=(181 ; 173 ; 8) \\
& D_{11}=\sqrt{(66-181)^{2}+(21-173)^{2}+(45-8)^{2}} \\
& =194,1597
\end{aligned}
$$

2. Proses Hitung cluster $\left(\mathrm{C}_{1}\right)$

$X_{2}=(66 ; 21 ; 45) \quad C_{1.2}=(96 ; 81 ; 15)$

$D_{12}=\sqrt{(66-96)^{2}+(21-81)^{2}+(45-15)^{2}}$

$=73,48469$

3. Proses Hitung cluster $\left(\mathrm{C}_{2}\right)$

$X_{3}=(66 ; 21 ; 45) \quad C_{1.3}=(302 ; 257 ; 45)$

$D_{1 \mathrm{a}}=\sqrt{(66-302)^{2}+(21-257)^{2}+(45-45)^{2}}$

$=333,7544$ 
Perform the calculation process for the above data up to 40 times according to the amount of data, the calculation results can be seen in table 2 obtained from the calculation of the Euclidean Distance in iteration I above, the comparison of the distance from each cluster $\mathrm{C} 0, \mathrm{C} 1, \mathrm{C} 2$ is obtained.

a. Grouping Data Into Each Cluster

After the data has been processed and calculated in the steps above, the results of the above process are grouped as follows:

Table 3: Cluster Data Clusters with the Closest Distance

\begin{tabular}{|c|c|c|c|c|c|c|}
\hline No & $\mathbf{C}_{\mathbf{0}}$ & $\mathbf{C}_{\mathbf{1}}$ & $\mathbf{C}_{\mathbf{2}}$ & $\begin{array}{c}\text { Jarak } \\
\text { Terdekat } \\
\mathbf{C}_{\mathbf{0}}\end{array}$ & $\begin{array}{c}\text { Jarak } \\
\text { Terdekat } \\
\mathbf{C}_{\mathbf{1}}\end{array}$ & $\begin{array}{c}\text { Jarak } \\
\text { Terdekat } \\
\mathbf{C}_{\mathbf{2}}\end{array}$ \\
\hline 1 & 194,15973 & 73,48469 & 333,7544 & & 1 & \\
\hline 2 & 199,76486 & 82,74056 & 336,1458 & & 1 & \\
\hline 3 & 190,51509 & 65,28399 & 335,44895 & & 1 & \\
\hline 4 & 150,73818 & 25,57342 & 298,15768 & & 1 & \\
\hline 5 & 0 & 125,4512 & 151,87495 & 1 & & \\
\hline 6 & 135,32184 & 71,37226 & 257,39852 & & 1 & \\
\hline 7 & 93,08061 & 40,47221 & 234,77223 & & 1 & \\
\hline 8 & 77,239886 & 78,43469 & 203,70567 & 1 & & \\
\hline 9 & 71,386273 & 54,461 & 218,57264 & & 1 & \\
\hline 10 & 195,36632 & 71,93052 & 337,47 & & 1 & \\
\hline 11 & 207,64874 & 82,42572 & 352,20165 & & 1 & \\
\hline 12 & 136,565 & 18,38478 & 280,08213 & & 1 & \\
\hline 13 & 98,173316 & 36,76955 & 239,61636 & & 1 & \\
\hline 14 & 154,61565 & 33,25658 & 297,47941 & & 1 & \\
\hline 15 & 59,866518 & 69,46942 & 203,16004 & 1 & & \\
\hline 16 & 93,155784 & 37,17526 & 236,61361 & & 1 & \\
\hline 17 & 172,72522 & 49,31531 & 315,8354 & & 1 & \\
\hline 18 & 125,45119 & 0 & 272,60227 & & 1 & \\
\hline 19 & 194,05669 & 70,02857 & 336,90355 & & 1 & \\
\hline 20 & 215,30908 & 89,87769 & 361,43326 & & 1 & \\
\hline 21 & 191,64551 & 68,94926 & 333,15762 & & 1 & \\
\hline 22 & 216,43013 & 91,78235 & 359,51078 & & 1 & \\
\hline 23 & 188,88621 & 65,55913 & 331,15253 & & 1 & \\
\hline 24 & 192,81079 & 68,27884 & 336,37776 & & 1 & \\
\hline 25 & 191,7707 & 67,63135 & 334,84026 & & 1 & \\
\hline 26 & 202,86449 & 77,76889 & 347,18295 & & 1 & \\
\hline 27 & 186,01613 & 61,18823 & 330,24839 & & 1 & \\
\hline 28 & 172,6731 & 59,71599 & 309,12457 & & 1 & \\
\hline 29 & 124,42669 & 43,1509 & 258,84745 & & 1 & \\
\hline 30 & 224,83327 & 100,04 & 367,98913 & & 1 & \\
\hline 31 & 151,87495 & 272,6023 & 0 & & & \\
\hline 32 & 301,84764 & 424,0118 & 151,45296 & & & \\
\hline 33 & 136,03676 & 35,69314 & 273,65307 & & 1 & \\
\hline 34 & 167,82729 & 204,7242 & 187,08287 & 1 & & \\
\hline
\end{tabular}




\begin{tabular}{|c|c|c|c|c|c|c|}
\hline 35 & 164,54179 & 169,1094 & 221,68897 & 1 & & \\
\hline 36 & 128,15615 & 183,0792 & 154,4215 & 1 & & \\
\hline 37 & 205,96602 & 81,03086 & 349,85997 & & 1 & \\
\hline 38 & 181,3946 & 64,94613 & 318,96395 & & 1 & \\
\hline 39 & 205,77172 & 80,94443 & 353,4855 & & 1 & \\
\hline 40 & 87,988636 & 44,45222 & 229,93912 & & 1 & \\
\hline \multicolumn{4}{|c|}{ Jumlah } & 6 & 32 & 2 \\
\hline
\end{tabular}

Based on the calculation process obtained in iteration I according to table 3 above, a cluster of each has been obtained where the results of $\mathrm{C} 0$ are 6 data, the results of $\mathrm{C} 1$ are 32 data and the results of $\mathrm{C} 2$ are 2 data.

1) Iteration Process II (Second)

From table 3 above, it is found that the group of members $\mathrm{C} 0, \mathrm{C} 1$ and $\mathrm{C} 2$ is the result of this group to get new centroid values as follows :

a. Anggota cluster $0(\mathrm{C} 0)$ terdiri dari 6 anggota

$$
\begin{array}{ll}
\mathrm{C} 1(\mathrm{X} 1) & =(181+160+149+252+213+243) / 6 \\
\mathrm{C} 1(\mathrm{X} 1) & =\mathbf{1 9 9 , 6 6 6 7} \\
\mathrm{C} 1(\mathrm{Y} 2) & =(173+111+125+107+76+131) / 6 \\
\mathrm{C} 1(\mathrm{Y} 2) & =\mathbf{1 2 0 , 5} \\
\mathrm{C} 1(\mathrm{Z} 3) & =(8+49+24+145+137+112) / 6 \\
\mathrm{C} 1(\mathrm{Z} 3) & =\mathbf{7 9 , 1 6 6 7}
\end{array}
$$

b. Anggota cluster $1(\mathrm{C} 1)$ terdiri dari 32 anggota

$$
\begin{aligned}
\mathrm{C} 2(\mathrm{X} 1)= & (66+70+55+77+135+129+135+59+44+96+126+85+126 \\
& +72+96+58+34+63+42+63+57+59+48+60+87+121+36 \\
& +108+47+79+36+132) / 32 \\
\mathrm{C} 2(\mathrm{X} 1)= & \mathbf{7 8 , 1 5 6 3} \\
\mathrm{C} 2(\mathrm{Y} 2)= & (21+14+31+64+63+99+119+23+18+68+95+54+100+41 \\
& +81+25+16+25+9+28+27+27+21+33+35+72+3+64+18 \\
& +29+27+103) / 32 \\
\mathrm{C} 2(\mathrm{Y} 2) & \mathbf{4 5 , 4 0 6 3} \\
\mathrm{C} 2(\mathrm{Z} 3) & (45+56+24+13+72+30+16+36+26+28+31+31+26+31 \\
& +15+33+18+38+33+35+30+32+27+27+52+49+33+44+29 \\
& +50+9+29) / 32 \\
\mathrm{C} 2(\mathrm{Z} 3) & \mathbf{3 2 , 7 5}
\end{aligned}
$$

c. Anggota cluster $2(\mathrm{C} 2)$ terdiri dari 2 anggota

$$
\begin{array}{ll}
\mathrm{C} 3(\mathrm{X} 1) & =(302+415) / 2 \\
\mathrm{C} 3(\mathrm{X} 1) & =\mathbf{3 5 8}, \mathbf{5} \\
\mathrm{C} 3(\mathrm{Y} 2) & =(257+357) / 2 \\
\mathrm{C} 3(\mathrm{Y} 2) & =\mathbf{3 0 7} \\
\mathrm{C} 3(\mathrm{Z} 3) & =(45+58) / 2 \\
\mathrm{C} 3(\mathrm{Z} 3) & =\mathbf{5 1 , 5}
\end{array}
$$

After the above calculation process is complete, a new centroid will be obtained which can be seen in table 4 with the following values:

Table 4: Second Iteration New Centroid Value

\begin{tabular}{|c|c|c|c|}
\hline Centroid & Pembelian & Penjualan & Sisa Stok \\
\hline $\mathbf{C}_{\boldsymbol{0}}$ & 199,6667 & 120,5 & 79,1667 \\
\hline $\mathbf{C}_{\boldsymbol{1}}$ & 78,1563 & 45,41 & 32,75 \\
\hline $\mathbf{C}_{\boldsymbol{2}}$ & 358,5 & 307 & 51,5 \\
\hline
\end{tabular}

After obtaining the new centroid, then iterating again like the above calculation process by calculating the center of cluster 0 , cluster 1 and cluster 2 of each centroid using the Euclidean Distance (D) formula in iteration II, the above process is repeated until the 
iteration does not change the centroid value in Before and after iterations, this study stopped at the 6th iteration after the centroid values did not change. Then the result is that cluster $0(\mathrm{C} 0)$ for not selling there are 13 data, cluster $1(\mathrm{C} 1)$ for best-selling has 25 data and cluster $2(\mathrm{C} 2)$ for very in demand there are 2 data. More details about Mazaya product grouping can be seen in table 5 as follows :

Table 5: Overall Grouping Results

\begin{tabular}{|c|c|c|c|c|}
\hline NO & PEMBELIAN & PENJUALAN & SISA STOK & KEPUTUSAN \\
\hline 1 & 66 & 21 & 45 & LARIS \\
\hline 2 & 70 & 14 & 56 & LARIS \\
\hline 3 & 55 & 31 & 24 & LARIS \\
\hline 4 & 77 & 64 & 13 & LARIS \\
\hline 5 & 181 & 173 & 8 & TIDAK LARIS \\
\hline 6 & 135 & 63 & 72 & TIDAK LARIS \\
\hline 7 & 129 & 99 & 30 & TIDAK LARIS \\
\hline 8 & 160 & 111 & 49 & TIDAK LARIS \\
\hline 9 & 135 & 119 & 16 & TIDAK LARIS \\
\hline 10 & 59 & 23 & 36 & LARIS \\
\hline 11 & 44 & 18 & 26 & LARIS \\
\hline 12 & 96 & 68 & 28 & LARIS \\
\hline 13 & 126 & 95 & 31 & TIDAK LARIS \\
\hline 14 & 85 & 54 & 31 & LARIS \\
\hline 15 & 149 & 125 & 24 & TIDAK LARIS \\
\hline 16 & 126 & 100 & 26 & TIDAK LARIS \\
\hline 17 & 72 & 41 & 31 & LARIS \\
\hline 18 & 96 & 81 & 15 & LARIS \\
\hline 19 & 58 & 25 & 33 & LARIS \\
\hline 20 & 34 & 16 & 18 & LARIS \\
\hline 21 & 63 & 25 & 38 & LARIS \\
\hline 22 & 42 & 9 & 33 & LARIS \\
\hline 23 & 63 & 28 & 35 & LARIS \\
\hline 24 & 57 & 27 & 30 & LARIS \\
\hline 25 & 59 & 27 & 32 & LARIS \\
\hline 26 & 48 & 21 & 27 & LARIS \\
\hline 27 & 60 & 33 & 27 & LARIS \\
\hline 28 & 87 & 35 & 52 & LARIS \\
\hline 29 & 121 & 72 & 49 & TIDAK LARIS \\
\hline 30 & 36 & 3 & 33 & LARIS \\
\hline 31 & 302 & 257 & 45 & SANGAT LARIS \\
\hline 32 & 415 & 357 & 58 & SANGAT LARIS \\
\hline 33 & 108 & 64 & 44 & LARIS \\
\hline 34 & 252 & 107 & 145 & TIDAK LARIS \\
\hline 35 & 213 & 76 & 137 & TIDAK LARIS \\
\hline 36 & 243 & 131 & 112 & TIDAK LARIS \\
\hline
\end{tabular}




\begin{tabular}{|l|c|c|c|c|}
37 & 47 & 18 & 29 & LARIS \\
\hline 38 & 79 & 29 & 50 & LARIS \\
\hline 39 & 36 & 27 & 9 & LARIS \\
\hline 40 & 132 & 103 & 29 & TIDAK LARIS \\
\hline
\end{tabular}

\section{CONCLUTION}

The K-Means Clustering method was successfully applied to classify Mazaya products which consisted of not selling, selling well and being very in demand. The results of this study can facilitate PT. Bougenville Anugrah in optimizing the stock of Mazaya products. Based on the data used to classify Mazaya products from March to July 2019 with a total of 40 pieces of data. Obtaining the results of grouping that cluster $0(\mathrm{C} 0)$ for not selling are 13 data, cluster 1 (C1) is for best-selling as much as 25 data and cluster 2 (C2) for best-selling as much as 2 data. So that for products in cluster 2 the stock can be expanded to reduce stock shortages, and for cluster 0 to reduce the amount of stock in order to minimize costs.

\section{REFERENCE}

[1] K. Fatmawati, dan A. P. Windarto, "Data Mining: Penerapan Rapidminer Dengan K-Means Cluster Pada Daerah Terjangkit Demam Berdarah Dengue (DBD) Berdasarkan Provinsi”, CESS (Journal of Computer Engineering System and Science), vol. 3 no. 2, hal. 173-178, 2018. doi: 10.24114/cess.v3i2.9661.

[2] I. Parlina, A. P. Windarto, A. Wanto, dan M. R. Lubis, “ Memanfaatkan Algoritma K-Means Dalam Menentukan Pegawai Yang Layak Mengikuti Asessment Center Untuk Clustering Program SDP”, CESS (Journal of Computer Engineering System and Science), vol. 3, no. 1, hal. 87-93, 2018. doi: 10.24114/cess.v3i1.8192.

[3] Gustientiedina, M. H. Adiya, dan Y. Desnelita, "Penerapan Algoritma K-Means Untuk Clustering Data Obat-Obatan Pada RSUD Pekanbaru”, Jurnal Nasional Teknologi dan Sistem Informasi, vol. 5, no. 1, hal. 17-24, 2019. doi: https://doi.org/10.25077/ TEKNOSI.v5i1.2019.17-24.

[4] N. Agustina, dan Prihandoko, "Perbandingan Algoritma K-Means Dengan Algoritma Fuzzy C-Means Untuk Clustering Tingkat Kedisiplinan Kinerja Karyawan”, Jurnal RESTI (Rekayasa Sistem dan Teknologi Informasi), vol. 2, no. 3, hal. 621-626, 2018. doi: https://doi.org/10.29207/resti.v2i3.492.

[5] F. Yunita, "Penerapan Data Mining Menggunakan Algoritma K-Means Clustring Pada Penerimaan Mahasiswa Baru (Studi Kasus: Universitas Islam Indragiri)", SISTEMASI, vol. 7, no. 3, hal. 238-249, 2018. doi: 10.32520/stmsi.v7i3.388.

[6] D. Triyansyah, dan D. Fitrianah, "Analisis Data Mining Menggunakan Algoritma K-Means Clustering Untuk Menentukan Strategi Marketing”, IncomTech, Jurnal Telekomunikasi dan Komputer, vol. 8, no. 3, hal. 163-182, 2018. doi: 10.22441/incomtech.v8i2.4174.

[7] I. W. A. W. Kusuma, dan R. L. Ellyana, "Penerapan Citra Terkompresi Pada Segmentasi Citra Menggunakan Algoritme K-MEANS", JUTEI, vol. 2, no. 1, hal. 65-74, 2018 . doi: 10.21460/jutei.2018.21.65.

[8] F. Mahmuda, M. Sitorus, H. Widyastuti, dan D. Kurniawan, "Clustering Profil Pengunjung Perpustakaan Menggunakan Algoritma K-Means”, JAIC, vol. 1, no. 1, Hal. 14-21, Oct. 2018. 